\title{
Identifying Strategic Development Objectives for European Union's Potential Candidate States Using Dominance-Based Rough Set Approach: Case Study of Bosnia and Herzegovina
}

\author{
Bryan Trudel, Jean-Charles Marin, Kazimierz Zaras \\ Université du Québec en Abitibi-Témiscamingue, Rouyn-Noranda, Canada \\ Email: bryan.trudel@uqat.ca,marj103@uqat.ca, kazimierz.zaras@uqat.ca
}

How to cite this paper: Trudel, B., Marin, J.-C. and Zaras, K. (2018) Identifying Strategic Development Objectives for European Union's Potential Candidate States Using Dominance-Based Rough Set Approach: Case Study of Bosnia and Herzegovina. Modern Economy, 9, 1452-1464.

https://doi.org/10.4236/me.2018.98092

Received: July 23, 2018

Accepted: August 24, 2018

Published: August 27, 2018

Copyright $\odot 2018$ by authors and Scientific Research Publishing Inc. This work is licensed under the Creative Commons Attribution International License (CC BY 4.0). http://creativecommons.org/licenses/by/4.0/

\section{Open Access}

\begin{abstract}
This research is the second of a series of three researches to cope with strategic development objectives using Dominance-based Rough Set Approach (DRSA). The objective of this article is to expose the results of a research using DRSA to help the European Union (EU) identifying political, economical, sociological and technological strategic objectives for potential candidate countries planning to join the EU. Using the proposed methodology, politicians and leaders will be able to prioritize strategic development objectives according to political, economical, sociological and technological (PEST) needs of a specific candidate country to the EU. More precisely, the proposed methodology classifies all the European Union's countries according to the following three different categories: $[\mathrm{A}] \mathrm{EU}$ countries that are doing well according to the selected indicators; [B] EU countries that need support to acquire category A status; [C] EU countries ranked the lowest and needing special support with regard to the criterion or criteria considered. The three categories are delimited by tertiles relative to the average ranking of all EU countries including a potential candidate country, Bosnia and Herzegovina. Afterwards, DRSA provides decision rules based on this classification. These decision rules thus focus on the PEST needs of countries with respect to improve their development and classification by pointing out what was needed to be part of the different categories. We strongly believe that by targeting these identified needs, this research will help the development of the European Union's economy, target and prioritize economical and sociological improvements with the use of strategic objectives for any candidate country. One of the results concerning our case study with Bosnia and Herzegovina is about the fact that this potential country has a weakness in the percentage of women in politics. Indeed,
\end{abstract}


our research as shown that this criterion has an impact for the overall classification of the EU countries.

\section{Keywords}

International Development, African Countries, International Aid, Economic Growth, Strategic Objectives, Rough Set Theory, Dominance-Based Rough Set Approach (DRSA), Selection of Portfolio Projects, Multi-Criteria Analysis, Sustainable Development

\section{Introduction}

This is the second research of a series of three articles using a systematic approach using a combination of statistics and DRSA to help specific territories identifying strategic objectives to improve their development. The first article dealt with all the African countries. This second article uses the same methodology to determine strategic objectives for potential candidate countries for the European Union with the case of Bosnia-Herzegovina. The third article will help identify poverty for all the United Nations countries and strategic objectives for sustainable development.

The systematic approach begins with a selection of statistical data taken from different census, the World Bank and various indexes. These variables were separate over four different perspectives (Political, Economical, Sociological and Technological). The ranking of all the selected country according to these perspectives could then be performed with the weighted average. The final step is the use of DRSA to identify decision rules and conditions for each country. These conditions represent strategic objectives in order to improve the country development compared to others. This research deals with all the countries of the European Union and we included a potential candidate (Bosnia-Herzegovina). Therefore, the systematic approach will categorize Bosnia-Herzegovina within the European Union and determine decision rules in order to improve its development thru the identified conditions which should be considered as its own strategic objectives.

\section{Literature Review}

The European Union is a union of states where public policies are discussed in order to solve sociological and economical problems that member states, if were alone, would have difficulties facing them [1]. The European Council of Bruxelles of 2006 came with the notion that the addition of new states must take into account the capacity, of the EU, to integrate new members [2]. When in the process of joining the EU, several political, sociological, economical, legal and cultural issues are studied and discussed between the members of the EU and the candidate state [3]. Afterwards, the candidate state must develop its national strategy. Slovenia is an excellent example of this process. In June 2005, the 
Slovenian government adopted the Slovenia's National Strategy which proposed strategic goals. For example, a first goal targeted the increase of the GDP per capita to exceed the average level of the EU. A second goal was and improvement of the quality of living [4]. The researchers understand the complexity of integrating a new state within the EU. Financial integration, legislative issues are just a few of the difficulties. This research proposes a systematic approach that identifies the asymmetries from a political, economical, sociological and technological perspective and proposes strategic objectives with specific targets for a potential candidate. We are proposing to apply this process to the country of Bosnia Herzegovina.

Firstly proposed by Pawlak [5] [6] and by Pawlak and Slowinski [7], the Rough set theory is a mathematical tool with the aim of supporting decision-making processes. Since its development, it's been used in many fields such as medecine, banking, engineering, learning, location selection, pharmacology, finance, market analysis and economics [8]-[17]. The approach was then broadened by Greco, Matarazo and Slowinski [9] and renamed the "Dominance-based Rough Set Approach" (DRSA). Then, Zaras enlarged it for mixed data (deterministic, probabilistic and fuzzy) [10]. The purpose of the present research is to use DRSA for developing strategic objectives for all EU countries in order to help their decision makers and leaders to target specific objectives to improve the political, economic, sociological and technological development of the EU. To do so, a group of experts has selected 22 variables which were categorized in four different perspectives (Political, Economical, Sociological and Technological). We believe that by integrating within the process a potential candidate along with the 28 countries of the EU, DRSA will be able to prioritize strategic objectives to help the decision makers with the introduction of a potential candidate within the EU. As a case study of a potential candidate, we selected Bosnia and Herzegovina.

In Section 3, we apply DRSA to classify all the EU countries with regards to the statistical data and propose decision rules for each category (countries classified as A, B and C). Section 4 shows a list of strategic objectives for Bosnia and Herzegovina. This list proposes strategic objectives and point out the thresholds to improve and monitor the sustainable development of Bosnia and Herzegovina if it was to join the EU in the future.

\section{Method}

\subsection{Political, Economical, Sociological and Technological Indicators}

A group of experts have been asked to select the variables based on the relevance, availability and level of interest of comparability between countries. At the end of the process, 22 variables were selected and categorized in four different perspectives: Political, Economical, Sociological and Technological. To obtain the data of these variables we navigated and searched through the website of the World Bank, the United Nations and also the International Institute for Strategic Studies [18] [19] [20] during the January to March 2018 period. Data were dis- 
tributed into four perspectives, namely political, economic, sociological and technological (PEST) as summarized in Table 1. In case of missing data we compare states by weighting the average.

Table 1. Summary of the PEST indicators considered in this research.

\begin{tabular}{llc}
\hline Perspectives and Measurement & Definition & $\begin{array}{c}\uparrow=\text { High is better } \\
\downarrow=\text { Low is better }\end{array}$ \\
\hline
\end{tabular}

\section{Political}

1.1 Global Peace Index

1.2 Military expenditure

1.3 Corruption perception index

1.4 Global competitiveness index

1.5 Ease of doing business index

1.6 Women in government

\section{Economical}

2.1 Adjusted net national income per capita

2.2 GNP per capita

2.3 GNI per capita

2.4 Unemployment

2.5 Exports of G\&S

\section{Sociological}

3.1 Life expectancy, female

3.2 Life expectancy, male

3.3 School life

3.4 Urban population

3.5 Adolescent fertility

3.6 Homicides

\section{Technological}

4.1 Academic papers

4.2 Internet

4.3 Fixed Internet

4.4 Secure internet

4.5 Mobile phones
Number of battle deaths from internal conflict between at least one government armed forces (2017).

Cash outlays of central or federal government to meet the costs of national armed forces (2017).

A ranking of countries according to the extent to which corruption is believed to exist (2017).

Competitiveness along various pillars (2017).

Ease of doing business index (2017).

Proportion of seats held by women in national parliaments (2017).

Adjusted net national income per capita (Current USD 2017)

Gross National Product (USD Constant 2016) divided by capita. Gross National Income per capita Atlas method (Current USD 2017).

Unemployment, total (\% of labor force 2017).

Exports of goods and services (\% of GNP 2017).

Life expectancy at birth, female (years 2017).

Life expectancy at birth, male (years 2017).

School life expectancy (2017).

Percentage of urban population (2017).

Number of births per 1000 women ages 15 - 19 (2017).

Intentional homicide refers to death deliberately inflicted on a person by another person (2017).

Number of scientific published papers per capita (2017).

Percentage of active population using the internet (2017)

Fixed broadband internet subscriptions per 100 people (2017).

Secure internet servers per million people (2017).

Mobile cellular subscription per 100 people (2017).

\section{Scale $1-5$}

Scale $1-5$

Scale $0-100$

Scale $1-7$

Ranking of world country

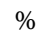

$\%$

Number of years

Number of years

Number of years

$\%$

Number

Scale 1 - 5

Number

$\uparrow$

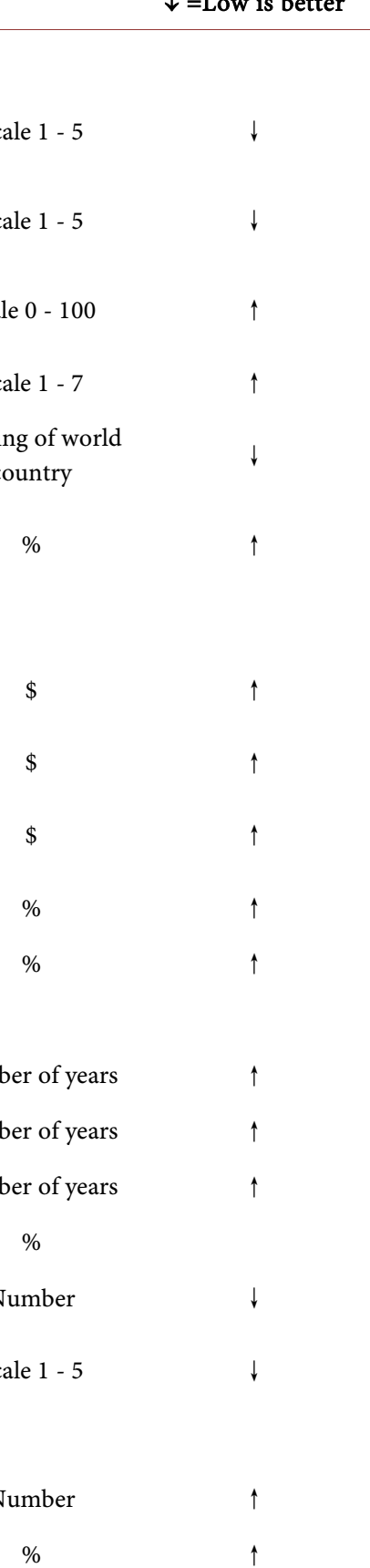

Number

Number

$\uparrow$

Number

$\uparrow$ 


\subsection{The Dominance-Based Rough Set Approach (DRSA) Applied to Determine the Strategic Developmental Objectives of Bosnia and Herzegovina}

In order to determine the strategic objectives of Bosnia and Herzegovina for improving its overall classification, the methodology of the Dominance-based Rough Set Approach (DRSA) were performed. This methodology begins with the classification of all the EU countries for each perspectives in category A, B or C: Category $[\mathrm{A}] \mathrm{EU}$ countries that are doing well according to the selected indicators; [B] EU countries that need support to acquire category A status; [C] EU countries ranked the lowest and needing special support with regard to the criterion or criteria considered. These classifications are presented in Table 2, where all the $29 \mathrm{EU}$ countries are categorized with respect to the four perspectives (PEST) and also on the combined of all perspectives (Decision column). Afterword, decision rules are extracted for all the perspectives combined, and also for each individual perspective (PEST). Finally, the potential candidate for joining the EU, in this case Bosnia and Herzegovina, identifies its strategic objectives with regards to their respective variables and performance.

\subsection{Formulation of the Multi-Criteria Problems}

Our first task was to get the overall ranking of the 29 countries on the basis of the 22 criteria measured by 22 indicators. Secondly, we did the same but for each perspective according to its respective criteria. That approach can be described with the use of the AXE model, where:

- $\quad A$ is a finite set of countries $a_{i}$ for $i=1,2, \ldots, 29$;

- $\quad X$ is a finite set of criteria $X_{k}$ for $k=1,2, \cdots, 22$ or $X_{k j}$ for $k_{j}=1,2, \cdots, n_{j}$ for each perspective $j$.

- $E$ is the set of evaluations measured by indicators $e_{i k}$ with respect to criterion $X_{k}$ or indicators $e_{i k j}$ with respect to criterion $X_{k j}$ for each perspective $j$.

The weighted average rank method was used to obtain the ranking of countries. Thus, countries were ranked from the most to the least preferable in regards of each indicator in relation to each criterion. Afterword, since weights of indicators are considered equal, we calculated the weighted average rank for each country. This enables us to obtain the ranking of the countries with respect to a given perspective as well for the overall classification.

For each perspective $j$, the weighted average of country $i$,

$$
r_{i j}=\sum_{k j} w_{k j} r_{k i j}
$$

The overall weighted average of country $i$

$$
r_{i}=\sum_{k} w_{k} r_{k i}
$$

where:

$w_{k}$ is the weight of criterion $k$ and $w_{k j}$ for perspective $j$;

$r_{k i}$ is a rank of country $i$ with respect to criterion $k$ and $r_{k i j}$ for perspective $j$. 
Table 2. Overall classification of the 29 UE countries (including Bosnia and Herzegovina) according to the four perspectives.

\begin{tabular}{|c|c|c|c|c|c|}
\hline Decision & Countries & Political & Economical & Sociological & Technological \\
\hline A & Netherlands & A & A & A & A \\
\hline A & Danemark & A & A & A & A \\
\hline A & Luxembourg & B & A & A & A \\
\hline A & Sweden & A & A & A & A \\
\hline A & Finland & A & B & A & A \\
\hline A & Austria & A & A & A & A \\
\hline A & UK & B & A & B & A \\
\hline A & Germany & A & A & B & A \\
\hline A & Belgium & A & A & A & A \\
\hline A & Irland & A & A & B & B \\
\hline B & Estonia & B & B & C & A \\
\hline B & Malta & C & A & B & B \\
\hline B & France & B & B & B & B \\
\hline B & Slovenia & B & B & B & B \\
\hline B & Czech Republic & B & B & B & B \\
\hline B & Spain & A & B & A & B \\
\hline B & Cyprus & C & B & B & B \\
\hline B & Portugal & A & C & B & C \\
\hline B & Italy & C & B & A & B \\
\hline B & Poland & B & $\mathrm{C}$ & B & C \\
\hline C & Lithuania & B & C & C & B \\
\hline $\mathrm{C}$ & Slovak Rep. & B & B & $\mathrm{C}$ & $\mathrm{C}$ \\
\hline C & Hungary & B & B & $\mathrm{C}$ & C \\
\hline C & Latvia & C & C & $\mathrm{C}$ & B \\
\hline $\mathrm{C}$ & Greece & C & C & A & C \\
\hline $\mathrm{C}$ & Croatia & $\mathrm{C}$ & $\mathrm{C}$ & $\mathrm{C}$ & $\mathrm{C}$ \\
\hline $\mathrm{C}$ & Bulgaria & $\mathrm{C}$ & C & $\mathrm{C}$ & $\mathrm{C}$ \\
\hline $\mathrm{C}$ & Romania & C & $\mathrm{C}$ & $\mathrm{C}$ & C \\
\hline $\mathrm{C}$ & Bosnia-Herz & $\mathrm{C}$ & $\mathrm{C}$ & $\mathrm{C}$ & $\mathrm{C}$ \\
\hline
\end{tabular}

With the classifications of 29 countries, overall and for each perspective, the following step is to group them into three categories A, B and C. Table 2 presents these classifications of the 29 European Union countries according to the four perspectives as well for the overall one presented in first column.

The analysis of a country position by his decision makers, Bosnia and Herzegovina in our case, would certainly lead them to take actions in order to improve its rank and furthermore, to improve its chance to join the EU. Table 2 shows that 
Bosnia and Herzegovina is in Class C. What would be needed to move on and be part of class B or A isn't obvious at all. The answer on questions, which criteria should be considered and which are their critical values? would be a very precious information for decision makers. The proposed DRSA explanatory method allows us to identify these criteria as well as their critical values, thru the extraction of decision rules.

\subsection{Geographical Analysis of the Overall Classification Decision}

Regarding the overall classification in Table 2, we can notice that most countries categorized in $\mathrm{C}$ are geographically located in the South-East region of the European Union. A map of the EU showing that fact is presented in Appendix A. As it was the case in the first article about Africa [21], we still have the same phenomenon that we named the "Poverty String", since all the countries in the C category are all connected to one another.

\subsection{The Decision Rules}

To get the decision rules we used the 4eMka2 software [22], which was developed by the Intelligent Decision Support Systems laboratory (IDSS) at the computing science institute of the Poznan University of Technology. Rules for all the various perspectives combined are presented below in Table 3 . Since we wanted to get the most significant combination, we only kept rules with a minimal relative strength of $20 \%$ and those that were limited to 4 conditional criteria.

Rules 1 and 2 indicate that a country with a population percent of Internet user is at least $95.51 \%$ or if School life is at least equal to 19 years, then the country is classified in the class A, no matter the other criteria. Rules 3 and 4 dictate that if the percent of women in politics is at least $36.7 \%$ or if mobile phone subscriptions are at least 146.21 per 100 people, then the country is classified to the class B.

Following the same analysis, we can tie strategies for each of the four PEST perspectives. Table 4 describes the rules for each of the four PEST perspectives.

\section{Strategic Decision-Making}

This section demonstrates the practical application of the decision rules for Bosnia and Herzegovina and the usefulness of these rules for sustainable political, economical, sociological and technological development of the selected country,

Table 3. Decision Rules for all perspectives combined.

\begin{tabular}{ccc}
\hline$\#$ & Decision Rules & Condition 1 \\
\hline 1 & Decision $\geq$ A & Internet $\geq 95.51 \%$ of population \\
2 & Decision $\geq$ A & School life $\geq 19$ years \\
3 & Decision $\geq$ B & Women in politics $\geq 36.7 \%$ \\
4 & Decision $\geq$ B & Mobile phone $\geq 146.21$ subscriptions per 100 people
\end{tabular}


Table 4. Decision Rules for each perspective (PEST).

\begin{tabular}{|c|c|c|c|c|}
\hline$\#$ & Decision Rules & Condition 1 & Condition 2 & Condition 3 \\
\hline \multicolumn{5}{|c|}{ Political Perspective } \\
\hline 5 & Decision $\geq \mathrm{A}$ & Corruption Index $\geq 83$ & & \\
\hline 6 & Decision $\geq \mathrm{A}$ & Military exp. $\leq 1.47$ & Ease of doing bus. $\leq 29$ & \\
\hline 7 & Decision $\geq \mathrm{A}$ & Competitiveness Index $\geq 5.65$ & & \\
\hline 8 & Decision $\geq \mathrm{B}$ & Corruption Index $\geq 58$ & & \\
\hline 9 & Decision $\geq \mathrm{B}$ & Military exp. $\leq 1.52$ & Ease of doing bus. $\leq 48$ & \\
\hline \multicolumn{5}{|c|}{ Economical Perspective } \\
\hline 10 & Decision $\geq \mathrm{A}$ & GNI per capita $\geq 34,786.23 \$$ & & \\
\hline 11 & Decision $\geq \mathrm{B}$ & GNI per capita $\geq 34,550.80 \$$ & & \\
\hline 12 & Decision $\geq \mathrm{B}$ & Export of G\&S $\leq 89.54 \%$ & & \\
\hline 13 & Decision $\geq \mathrm{B}$ & Export of G\&S $\leq 78.98 \%$ & GNI per capita $\geq 17,750 \$$ & Unemployment $\leq 7.3 \%$ \\
\hline \multicolumn{5}{|c|}{ Sociological Perspective } \\
\hline 14 & Decision $\geq \mathrm{A}$ & Life Expectancy Men $\geq 80$ years & & \\
\hline 15 & Decision $\geq \mathrm{A}$ & Homicides $\leq 1.25$ & School life $\geq 16$ years & \\
\hline 16 & Decision $\geq \mathrm{A}$ & School life $\geq 19$ & $\begin{array}{l}\text { Adolescent Fertility } \leq 6.38 \text { per } \\
1000\end{array}$ & \\
\hline 17 & Decision $\geq \mathrm{B}$ & Life Expectancy Men $\geq 74.4$ years & & \\
\hline \multicolumn{5}{|c|}{ Technological Perspective } \\
\hline 18 & Decision $\geq \mathrm{A}$ & Internet $\geq 86.52 \%$ & & \\
\hline 19 & Decision $\geq \mathrm{B}$ & Secure Internet $\geq 768.58$ per million & & \\
\hline 20 & Decision $\geq \mathrm{B}$ & Mobile Phones $\geq 131.16$ per 100 & $\begin{array}{l}\text { Fixed Internet } \geq 25.43 \\
\text { subscriptions per } 100\end{array}$ & \\
\hline
\end{tabular}

potential candidate for joining the European Union. In order to create strategic objectives for Bosnia and Herzegovina, if the country was to join the EU, decision makers should follow the decision rules which dictate the targets of strategic objectives to improve. These targets are based on the statistical data used to extract the decisional rules.

Table 5 describes all the various strategic objectives for the candidate country. The decision rules dictate the targets they should have reached for each strategic objectives. It may happen that some decision rules conditions are already met (military expenditure). In that case the strategic objective is to maintain its current value. All the other values become strategic objectives that are listed and which would have allowed Bosnia and Herzegovina to be rank B instead of C.

Bosnia Herzegovina is classified as $\mathrm{C}$ for the overall classification (see Table 2). In order to improve the country status compared to all other members of the $\mathrm{EU}$, the candidate country should consider the decision rules that explain what was needed to be part of category $B$.

For all the perspectives combined (overall classification), Bosnia Herzegovina has four decision rules, each of these rules has one strategic objective (see Decision 
Table 5. Strategic objectives and targets for Bosnia Herzegovina.

\begin{tabular}{|c|c|c|c|}
\hline All Perspectives & Strategic Objectives 1 & Strategic Objectives 2 & Strategic Objectives 3 \\
\hline Decision Rule \#1 & $\begin{array}{l}\text { Improve the number of internet users by } 26.18 \% \text { of } \\
\text { the population }\end{array}$ & & \\
\hline Decision Rule \#2 & Improve School life by 5 years & & \\
\hline Decision Rule \#3 & Increase women in politics by $15.3 \%$ & & \\
\hline Decision Rule \#4 & $\begin{array}{l}\text { Increase mobile cellular subscriptions by } 56.96 \text { per } \\
\qquad 100 \text { people }\end{array}$ & & \\
\hline Political Perspective & Strategic Objectives 1 & Strategic Objectives 2 & Strategic Objectives 3 \\
\hline Decision Rule \#5 & $\begin{array}{l}\text { Improve the corruption perception index by } 44 \\
\text { points }\end{array}$ & & \\
\hline Decision Rule \#6 & Maintain military expenditures ( $\%$ of GNP) $)^{*}$ & $\begin{array}{l}\text { Improve the ease of doing } \\
\text { business index by } 57 \text { points }\end{array}$ & \\
\hline Decision Rule \#7 & Improve the competitiveness index by 1.78 points & & \\
\hline Decision Rule \#8 & $\begin{array}{l}\text { Improve the corruption perception index by } 19 \\
\text { points }\end{array}$ & & \\
\hline Decision Rule \#9 & Maintain military expenditures (\% of GNP)* & $\begin{array}{l}\text { Improve the ease of doing } \\
\text { business index by } 38 \text { points }\end{array}$ & \\
\hline Economical Perspective & Strategic Objectives 1 & Strategic Objectives 2 & Strategic Objectives 3 \\
\hline Decision Rule \#10 & $\begin{array}{l}\text { Improve the gross national income by } \\
30,827.25 \$ \text { (US) per capita }\end{array}$ & & \\
\hline Decision Rule \#11 & $\begin{array}{l}\text { Improve the gross national income by } \\
30,591.82 \$ \text { (US) per capita }\end{array}$ & & \\
\hline Decision Rule \#12 & $\begin{array}{l}\text { Improve exports of goods and services by } 54.13 \% \text { of } \\
\text { GNP }\end{array}$ & & \\
\hline Decision Rule \#13 & $\begin{array}{l}\text { Improve exports of goods and services by } 43.57 \% \text { of } \\
\text { GNP }\end{array}$ & $\begin{array}{c}\text { Improve the gross national } \\
\text { income by } 13,791.02 \$ \text { (US) per } \\
\text { capita }\end{array}$ & $\begin{array}{l}\text { Reduce unemployment by } \\
18.5 \%\end{array}$ \\
\hline Sociological Perspective & Strategic Objectives 1 & Strategic Objectives 2 & Strategic Objectives 3 \\
\hline Decision Rules \#14 & Improve life expectancy for men by 5.83 years & & \\
\hline Decision Rules \#15 & $\begin{array}{l}\text { Improve homicides UN survey of crime and trends } \\
\text { index by } 0.4\end{array}$ & $\begin{array}{l}\text { Increase school life expectancy } \\
\text { by } 2 \text { years }\end{array}$ & \\
\hline Decision Rules \#16 & Increase school life expectancy by 5 years & $\begin{array}{l}\text { Reduce adolescent fertility by } \\
1.79 \text { per } 1000\end{array}$ & \\
\hline Decision Rules \#17 & Maintain life expectancy for men & & \\
\hline Technological Perspective & Strategic Objectives 1 & Strategic Objectives 2 & Strategic Objectives 3 \\
\hline Decision Rules \#18 & $\begin{array}{l}\text { Improve the number of internet users by } 17.19 \% \text { of } \\
\text { the population }\end{array}$ & & \\
\hline Decision Rules \#19 & $\begin{array}{l}\text { Increase sercure internet servers by } 731.05 \text { per } \\
\text { million }\end{array}$ & & \\
\hline Decision Rules \#20 & $\begin{array}{l}\text { Increase mobile cellular subscriptions by } 41.91 \text { per } \\
\qquad 100 \text { people }\end{array}$ & $\begin{array}{c}\text { Increase fixed broadband } \\
\text { internet subscriptions by } 8.06 \\
\text { per } 100 \text { people }\end{array}$ & \\
\hline
\end{tabular}

${ }^{\star}$ Negligible difference from decision rule target. 
Rules \#1, 2, 3 and 4, Table 5). The first strategic objective indicates that the number of internet users is low compared to other EU countries and requires an increase of internet users by $26.18 \%$ of the candidate's population. Since the population of Bosnia Herzegovina is 3.517 million people (2016), this represents giving access to internet to approximately 920,751 people to be in classified in A. Strategic objective 2 is the school life expectancy. Again, the candidate country should aim to increase school life of at least 5 years to be classified A. Decision rule \#3 indicates that Bosnia Herzegovina should encourage women to participate in politics. Compared to other countries, in order to be in category B, Bosnia Herzegovina should increase the number of women in politics by $15.3 \%$. Decision rule \#4 indicates that the number of mobile cellular subscriptions per 100 people is also low compared to other EU countries and should be improved by 56.96 per 100 to be in category B.

Table 5 shows all the various decision rules, strategic objectives and specific targets for all the perspectives combined (Decision Rules \#1-4) and each of the PEST perspectives individually (Decision Rules \#5-19). Decision makers may select the best strategic objectives with specific targets to improve the development and classification of Bosnia Herzegovina within the European Union.

\section{Conclusions}

This research has been demonstrated that the DRSA can be used to identify the political, economic, sociological and technological indicators that are relevant for strategic decision making. It has been shown, by the example of Bosnia-Herzegovina, that our approach can be useful in considering of the country's candidacy to join the European Union.

We acknowledge the complexity and hard work of annexing a new country to the EU, providing a country with specific strategic objectives and comparing itself to other EU country helps to better understand specific challenges to be addressed or combined with other processes.

Furthermore, when other data from future years will be available, this tool will have a strategic importance for the European Union decision makers to study tendencies, changes in political, economical, sociological and technological development. The decision makers will also probably note the changes in classification over time and make predictions. It will also enable any candidate countries to enlighten their significant weaknesses in order to improve them and finally, that means an overall improvement of their situation in regards of different perspectives. Also, most countries classified as $\mathrm{C}$ seem to be connected to one another in the South-East region of Europe. That being said, a particular attention should be given to other possible candidates from this part of Europe if they had to knock at EU door.

\section{Limits and Future Research}

As it was the case with the first article, this research is limited to the selected in- 
dicators. Which means that indicators related to culture, religion and the environment, to name a few were not considered. Thus, it would be interesting to introduce some of these variables in a future research using the proposed methodology.

Furthermore, several strategic objectives and targets for Bosnia Herzegovina were identified. For future researchers we suggest that all candidate countries to the European Union use the same methodology to identify their respective classification within the European Union, as well for their own strategic objectives. Decision makers, politicians and leaders could also propose researching for other specific political, economic, sociological and technological indicators to be studied. Finally, European Union leaders could target development projects, estimate and eventually measure the impact of these projects on the proposed indicators and better manage the allocated resources to the development of new candidates within the European Union.

We strongly believe that the methodology proposed in this research may be tested at a larger scale for all the countries of the United Nations, which is the subject of the third and last article using the proposed methodology to identify strategic development objectives.

\section{Conflicts of Interest}

The authors declare no conflicts of interest regarding the publication of this paper.

\section{References}

[1] Rozenber, O. (2015) Faut-Il continuer à étudier l'Union européenne? Politique Européenne, 50, 296-309.

[2] Guyader, M. (2007) Élargissements et intégration dans l'Union. Politique Etrangère, 2, 367-380. https://doi.org/10.3917/pe.072.0367

[3] Krulic, J. (2013) Croatie: Une adhésion si longtemps désirée à l'UE, La revue géopolitique.

[4] Kralj, D. and Markič, M. (2008) Processes Innovation and Sustainable Development. WSEAS Transactions on Environment and Development, 2, 99-110.

[5] Pawlak, Z. (1982) Rough Set. International Journal of Parallel Programming, 11, 341-356.

[6] Pawlak, Z. (1991) Rough Sets: Theoretical Aspects of Reasoning about Data. Kluwer Academic Publishing, Dordrecht. https://doi.org/10.1007/978-94-011-3534-4

[7] Pawlak, Z. and Slowinski, R. (1994) Rough Set Approach to Multi-Attribute Decision Analysis. European Journal of Operational Research, 72, 443-459. https://doi.org/10.1016/0377-2217(94)90415-4

[8] Pawlak, Z. (2002) Rough Set Theory and Its Applications. Journal of Telecommunications and Information Theory, 3, 7-10.

[9] Greco, S., Matarazzo, B. and Słowiński, R. (2001) Rough Sets Theory for Multi-Criteria Decision Analysis. European Journal of Operational Research, 129, 1-47. https://doi.org/10.1016/S0377-2217(00)00167-3

[10] Zaras, K. (2004) Rough Approximation of a Preference Relation by a Multi-Attribute 
Stochastic Dominance for Deterministic, Stochastic and Fuzzy Evaluation Problems. European Journal of Operational Research, 159, 196-206. https://doi.org/10.1016/S0377-2217(03)00391-6

[11] Zaras, K., Marin, J.-C. and Boudreau-Trudel, B. (2012) Dominance Rough Set Approach as a Decision-Making Method for the Selection of Sustainable Development Projects. American Journal of Operational Research, 2, 506.

[12] Ho, H., Fann, W., Chiang, H., Nguyen, P., Pham, D., Nguyen, P. and Nagai, M. (2016) Application of Rough Set, GSM and MSM to Analyze Learning Outcome-An Example Introduction to Education. Journal of Intelligent Learning Systems and Applications, 8, 23-38. https://doi.org/10.4236/jilsa.2016.81003

[13] Renaud, J., Thibault, J., Lanouette, R., Kiss, L.N., Zaras, K. and Fonteix, C. (2007) Comparison of Two Multi-Criteria Methods: Net Flow and Rough Set Methods for aid to Decision Making in a High Yield Pulping Process. European Journal of Operational Research, 177, 1418-1432. https://doi.org/10.1016/j.ejor.2005.04.013

[14] Marin, J., Zaras, K. and Boudreau-Trudel, B. (2014) Use of the Dominance-Based Rough Set Approach as a Decision Aid Tool for the Selection of Development Projects in Northern Quebec. Modern Economy, 5, 723-741. https://doi.org/10.4236/me.2014.57067

[15] Prema S. and Umamaheswari, P. (2016) Multitude Classifier Using Rough Set Jelinek-Mercer Naïve Bayes for Disease Diagnosis. Circuits and Systems, 7, 701-708. https://doi.org/10.4236/cs.2016.76059

[16] Songbian Z. (2016) Business Intelligence from Customer Review Management Using Rough Set Model. International Journal of Advanced Research, 4, 816-824.

[17] Emam, O., Farhan, M. and Abohany, A. (2017) Faults Repairing Analysis Using Rough Sets after Implementation of Labor Force Redistribution Algorithm: A Case Study in Telecom Egypt. Information Sciences Letter, 6, 39-48.

[18] World Bank (2018) Indicators. https://data.worldbank.org/indicator

[19] United Nations (2018) UN Data. http://data.un.org/Explorer.aspx?d=UNODC

[20] International Institute for Strategic Studies (2018) IISS. https://www.iiss.org

[21] Marin, J., Trudel, B. and Zaras, K. (2018) Identifying Strategic Development Objectives for African Countries Using Dominance-Based Rough Set Approach: The Povertry String Theory. Modern Economy, 9, 1262-1286. https://doi.org/10.4236/me.2018.97082

[22] Greco, S., Matarazzo, B. and Slowinski, R. (1999) The Use of Rough Sets and Fuzzy Sets in MCDM. In: Gal, T., Hanne, T. and Stewart, T., Eds., Advances in Multiple Criteria Decision Making, Kluwer Academic Publishers, Dordrecht, Boston, 14.1-14.59.

[23] Cartograf (2018) Carte de l'Europe. https://www.cartograf.fr/carte_europe.php 


\section{Appendix A}

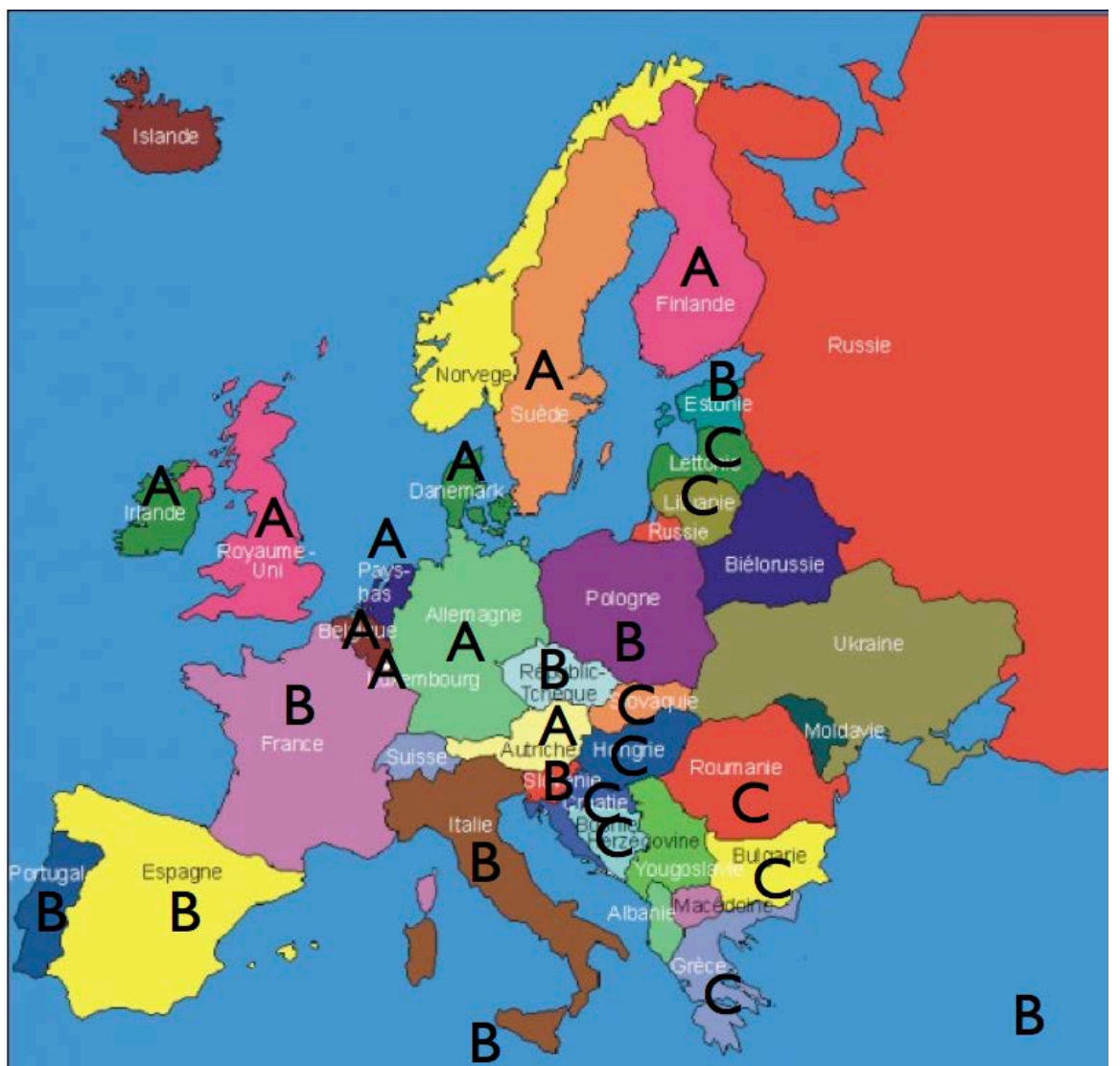

Cartograf (2018) Carte de l'Europe, viewed 8 January 2018.

https://www.cartograf.fr/carte_europe.php [23] 